\title{
METHODICAL APPROACHES TO ASSESSMENT OF FACTORS OF TOURISM COMPETITIVENESS OF THE REPUBLIC OF BELARUS
}

\author{
Svetlana Khomitch ${ }^{1}$ \\ Olga Mozgovaya ${ }^{2}$ \\ Vladimir Smoley ${ }^{3}$ \\ Alina Martsinovich ${ }^{4}$
}

DOI: https://doi.org/10.31410/tmt.2019.109

\begin{abstract}
In the chapter the basic European and international standards of the assessment of a national tourism product are considered. The key components of the Travel \& Tourism Competitiveness Index are analysed with a view to identifying specific factors which determine the competitive advantages of the country in the tourism market. In accordance with the World Economic Forum methodology, the assessment of the quantitative and qualitative indicators forming the competitiveness of the national tourism product of the Republic of Belarus is carried out. On the basis of the calculated subindices, SWOT-Clock analysis, and Competitive Advantages Profile the tourism competitiveness of the Republic of Belarus is estimated. The principal competitive advantages of the national tourism product are revealed with a view to improving the national tourism policy. A special algorithm for the elaboration of the tourism destination development strategy for any destination is compiled on the basis of the research.
\end{abstract}

Keywords: Tourism Competitiveness, Tourism Product, Competitiveness Assessment, Competitive Advantages, Tourism Destination Competitiveness Strategy, Travel \& Tourism Competitiveness Index, Republic of Belarus.

\section{INTRODUCTION}

$\mathrm{T}$ he assessment of the tourism product competitiveness becomes a key objective for the business entities of all the economic levels from microeconomy to macroeconomy. Firms at the microlevel are eager to gain more customers and profit than their competitors, while policy makers at the macrolevel strive for a bigger market share of the travel and tourism industry in the country's economy. Destination competitiveness as well as the factors that determine it has attracted considerable attention in the tourism researches, since it is regarded as a crucial factor for the success of tourism destinations. While there seems to be an agreement among the researchers on the main objectives and importance of competitiveness, there are many ways of measuring it.

Considering the fact that competitiveness is a complex concept embracing various elements, researchers have not agreed on one definition of the destination competitiveness. An attempt to develop a single definition that includes all aspects of the was made by Ritchie \& Crouch (2003): "what makes a tourism destination truly competitive is its ability to increase tourism expend-

1 Belarusian State University, Faculty of International Relations, Department of International Tourism; Minsk, Republic of Belarus

2 Belarusian State University, Faculty of International Relations, Department of International Tourism; Minsk, Republic of Belarus

3 Belarusian State University, Faculty of International Relations, Department of International Tourism; Minsk, Republic of Belarus

4 Belarusian State University, Faculty of International Relations, Department of International Tourism; Minsk, Republic of Belarus 
iture, to increasingly attract visitors while providing them with satisfying, memorable experiences, and to do so in a profitable way, while enhancing the well-being of destination residents and preserving the natural capital of the destination for future generations" (p. 2).

In spite of the lack of agreement on the destination competitiveness definition, all the researchers admit that competitiveness and its factors couldn't be assessed only on the basis of either quantitative or qualitative parameters. It's a complex economic category and hence the process of the tourism product or destination competitiveness assessment is supposed to include several stages with evaluation of various indicators and subindices, which subsequently form an overall index. The assessment of the destination competitiveness is a much more challenging task, because it includes evaluation of the quantitative and qualitative parameters from two types of economic spheres (the sphere of tourism and other spheres which enable the tourism industry development).

Numerous researches in the tourism industry provide their models of the destination competitiveness assessment. However, it is argued whether all of them can be used for a comprehensive assessment of the destination competitiveness. For example, some of the researches (Ritchie \& Crouch 1993, 2000, 2003; Dwyer \& Kim 2003; Gomezelj \& Mihalič 2008) include various indicators and determinants combined in groups, but it is assumed that these models do not cover all the aspects of the destination competitiveness.

All the modern models of the destination competitiveness assessment can be distinguished in accordance with various dimensions, as it is stated by numerous scholars (Popesku \& Pavlović 2015; Goffi \& Cucculelli 2016). One of them concerns the type of the indicators used in the research. Some of them can be based on objectively measured variables (or quantitative indicators), while others are based on the subjectively measured variables (or qualitative indicators). Such studies as Mazanec, Wober \& Zins (2007); Cracolici, Nijkamp \& Rietveld (2008) employ at their researches secondary data published by the international organisations in different spheres. In these studies, particular attention was paid to the quantitative parameters because they are usually seen as more precise and provide a higher level of objectivism.

However, according to many scholars it is highly unlikely to carry a fair assessment of the destination competitiveness using only quantitative indicators, as service industries (including tourism industry) are characterized by intangibility and invisibility of the service provided for consumers. For example, according to Ritchie \& Crouch (2010) there are several factors that reduce the quality of models when using quantitative data. Among them are the extremely wide range of indicators needed to create a high-quality model, the difficulty of finding statistical data for each of the aspects of competitiveness, and the abstractness and inaccuracy of some data sources.

Another type of the models is based on the subjectively measured variables or so-called 'soft measures'. In different approaches these qualitative indicators can be gathered either by asking tourists' opinions or tourism stakeholders' opinions. In their research Enright \& Newton (2004) claim that tourists can possibly evaluate the external components of the destination attractiveness (i.e. aspects of the destination competitiveness which are connected with the final product, but not with initial resources and conditions). Such researches were conducted by Kozak \& Rimmington (2000), Bahar \& Kozak (2007), Cracolici, Nijkamp, \& Rietveld (2008). At the same time, in order to assess the internal factors that influence and determine the competitive 
position of a tourist destination, one is supposed to gather opinions of the people who have some significant knowledge of what makes a tourism destination competitive. Such evaluation of subjective indicators of the destination competitiveness was carried out by such researchers as Enright \& Newton (2004, 2005); Gomezelj \& Mihalič (2008); Ritchie \& Crouch (2010).

A group of approaches to the assessment of the destination competitiveness is based on the implementation of the benchmarking tool. In this case such researchers as Reshetnikov (2004), Gračan, Milojica \& Zubovič (2008), Kapiki (2012) were not trying to quantify some indicators of the destination competitiveness. Instead, they base the analysis on the comparison of the tourism destinations within region.

\section{METHODOLOGY}

As an example of one of the most advanced solutions to the problem of the assessment of the national tourism product competitiveness, we can mention the methodology of the World Economic Forum (WEF). In the researches conducted by this organisation, both quantitative and qualitative parameters are considered.

Published biennially by the WEF, the Travel and Tourism Competitiveness Report benchmarks the Travel \& Tourism competitiveness of 140 economies and measures the set of factors and policies that enable the sustainable development of the Travel \& Tourism sector, which in turn, contributes to the development and competitiveness of a country.

The Travel \& Tourism Competitiveness Index assessed in the Report comprises of 4 subindices (Enabling Environment, Travel \& Tourism Policy and Enabling Conditions, Infrastructure, Natural and Cultural Resources) that are formed by 14 pillars. Each pillar represents an un-weighted average of various quantitative and qualitative indicators (total of 90 indicators in 14 pillars). The full list of indicators and their distribution among pillars is represented in Appendix C 'Data Definitions and Sources' of the Travel \& Tourism Competitiveness Report 2019.

The Enabling Environment subindex describes the general conditions necessary for operating in a country and includes five pillars. These are:

Pillar 1: 'Business Environment';

Pillar 2: 'Safety and Security';

Pillar 3: 'Health and Hygiene';

Pillar 4: 'Human Resources and Labour Market';

Pillar 5: 'ICT Readiness'.

The Travel \& Tourism Policy and Enabling Conditions subindex captures specific policies or strategic aspects that affect the Travel \& Tourism industry more directly and includes four pillars:

Pillar 6: 'Prioritization of Travel \& Tourism';

Pillar 7: 'International Openness';

Pillar 8: 'Price Competitiveness';

Pillar 9: 'Environmental Sustainability'.

The Infrastructure subindex captures the availability and quality of physical infrastructure of each country and includes three pillars, which represent the key components of the enabling infrastructure for the tourism industry. Among them: 
Pillar 10: 'Air Transport Infrastructure';

Pillar 11: 'Ground and Port Infrastructure';

Pillar 12: 'Tourist Service Infrastructure'.

The Natural and Cultural Resources subindex captures the principal recreational resources and includes two pillars, which enable the development of tourism in a particular country:

Pillar 13: 'Natural Resources';

Pillar 14: 'Cultural Resources and Business Travel'.

The assessment of these four subindices is carried out by the experts of the WEF through evaluation of 90 qualitative and quantitative parameters. The qualitative survey data is received from responses to the World Economic Forum's Executive Opinion Survey and ranges in value from 1 (worst) to 7 (best). The quantitative indicators used in the Travel \& Tourism Competitiveness Index are normalized to a 1-to-7 scale in order to align them with the Executive Opinion Survey's results.

This normalization is done using Formula 1 in case the higher value of the indicator is a positive factor in the tourism development (number of countries residents of which can arrive in a country for tourism purposes without obtaining visa; government expenditure on travel \& tourism development; number of World Heritage natural sites etc.) or using Formula 2 in case the lower value of the indicator has a positive impact on the tourism development (price level of hotel services; number of malaria incidences; time to start a business):

$$
\begin{aligned}
& \mathrm{Yi}=6 \times(\mathrm{Xi}-\mathrm{MIN}) /(\mathrm{MAX}-\mathrm{MIN})+1 \\
& \mathrm{Yi}=-6 \times(\mathrm{Xi}-\mathrm{MIN}) /(\mathrm{MAX}-\mathrm{MIN})+7
\end{aligned}
$$

Where:

Yi - Quantitative indicator score for a country, score (from 1 to 7);

$\mathrm{Xi}$ - Quantitative indicator value for a country, value;

MIN - Minimum value of this quantitative indicator among countries, value;

MAX - Maximum value of this quantitative indicator among countries, value.

One of the notes to mention is that the range of values of some indicators are large enough for different countries. With a view to handling this problem some adjustments were made in the calculations of the WEF to account for extreme outliers in the data. For this reason, in some cases normalized values of the indicators were used instead of the minimum and maximum values of the quantitative indicator among countries.

The Travel \& Tourism Competitiveness Index is calculated as an average (arithmetic mean) of the four component subindices, which are themselves calculated as averages (arithmetic means) of their pillars. Each of the pillars is calculated as an un-weighted average of the individual component indicators. The number of pillars per subindex decreases as the subindex becomes more directly linked to tourism sphere. As a result, the pillar weight increases.

For example, Natural Resources (pillar 13) has a higher weight than ICT Readiness (pillar 5) because the recreational resources play an important role in the development of a destination and are more relevant to the tourism industry; while the data captured in the ICT Readiness pillar repre- 
sents a broader set of various factors which don't influence the national tourism product directly, but have an indirect impact on the Enabling Environment for doing any business in the country.

With a view to visualizing the factors of the tourism destination competitiveness, as well as to identify its strengths and weaknesses, it is essential to build a competitive advantages profile, which could also clearly demonstrate the key directions of the destination development. While managing a destination, it is necessary to perform this stage regularly in order to trace the success of the tourism policy implementation and make necessary changes.

In order to expand the range of the methodical approaches to the assessment of the tourism destination competitiveness factors, the possibility of using other tools of the competitiveness evaluation was analysed. As a result, SWOT-Clock was proposed for the next stage of the assessment process. In addition, this tool enables the transition from the assessment of the competitiveness factors to the elaboration the tourism destination development strategy.

In the process of SWOT-Clock analysis on the basis of the conducted opinion survey, all the factors of tourism destination competitiveness are divided into four groups (Strengths and Weaknesses, Opportunities and Threats) depending on their impact on the country's competitive position. For each of these four groups of factors, an overall score is determined, which is then shown on the graph. After that, components on the same axis, i.e. strengths and weaknesses, as well as opportunities and threats, are added to find the point to which the strategy marker will be directed. Based on the calculated marker, it is possible to determine which type of strategy can be best applied to the destination: leverage, growth, response or survival strategy.

All the previous stages allowed gathering a large amount of information on the factors of the destination competitiveness and potential directions of its development. At this stage, the issue of applying all these data becomes particularly relevant, because the competitiveness assessment is usually not an objective of a study, but just a research tool. In this regard, the authors suggest that within the framework of the competitiveness assessment model a transition to the system of destination management should be made. Under the destination management one should understand the consistent and interconnected management of all the components (tangible and intangible) that form a destination, such as attractions, facilities, access, pricing, advertising, etc.

In this way destination management concept can be seen as a consecutive stage of the strategic planning. From the authors' point of view, this approach allows:

1. to elaborate the key development objectives of the tourism destination development strategy based on its strengths and weaknesses, opportunities and threats;

2. to introduce the subindices and pillars of the Travel \& Tourism Competitiveness Index as the key factors of the tourism development control;

3. to establish a system of monitoring the implementation of the tourism destination development strategy based on the key factors;

4. (in the long-term period) to carry out the transformation of the destination in accordance with the new balance system, in which a balance between impact and response exists.

For the successful implementation of the model, the processes of competitiveness assessment and strategy performance analysis should be executed continuously. In the framework of the 
model, the set of indicators used for the assessment of competitiveness is being constantly improved and a monitoring system is being developed, which allows collecting accurate data on the selected indicators.

In order to systematise the process of the assessment of the tourism destination competitiveness factors, the authors developed an algorithm, which can be used for the elaboration of the tourism destination development strategy for any destination (Figure 1). The algorithm is based on the classic models of strategic management which using the original data, can help develop a strategy, establish the management system, and define control mechanism.

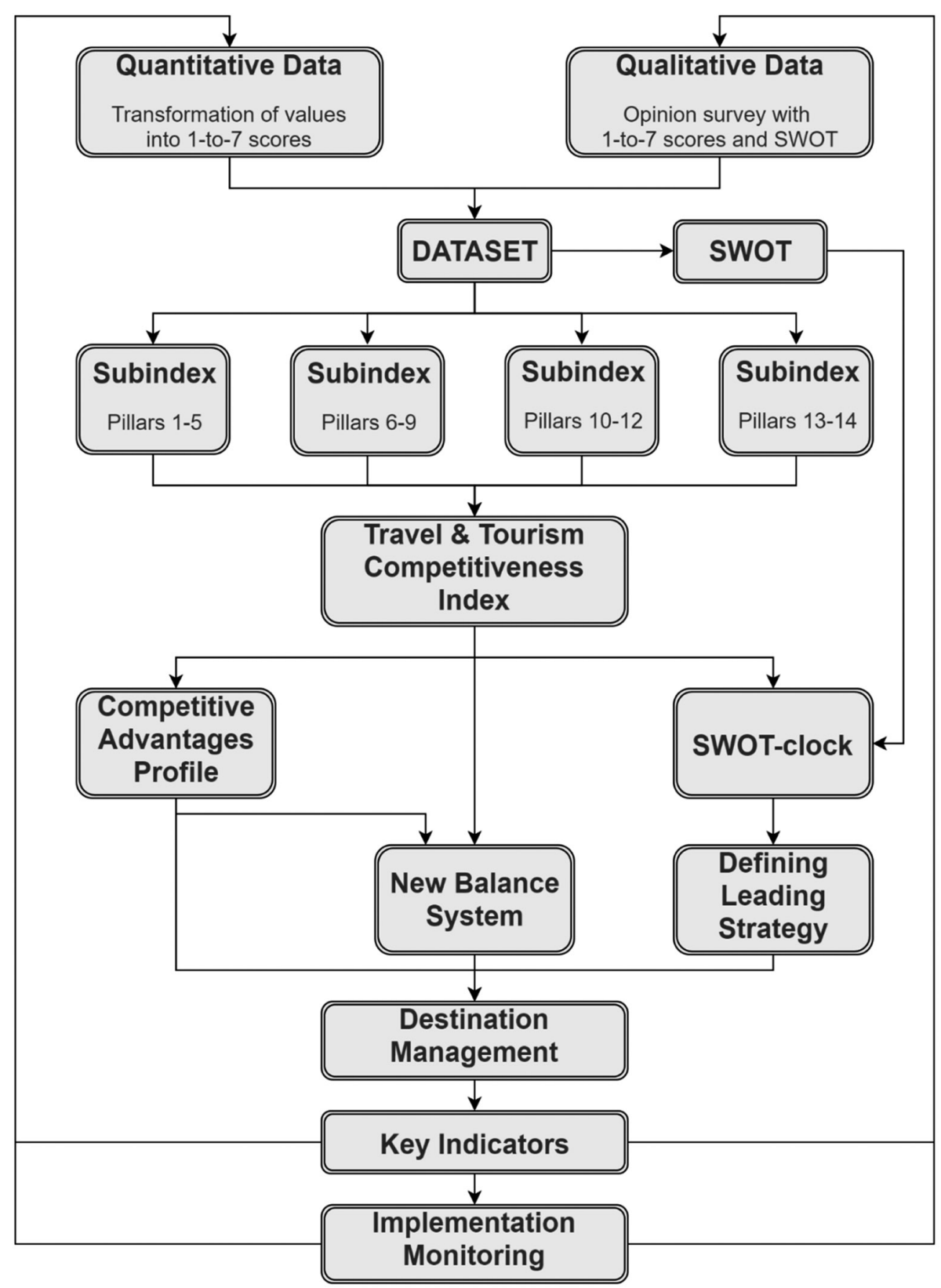

Figure 1. Algorithm of the Assessment of Tourism Destination Competitiveness Factors for the Purpose of the Elaboration of Tourism Destination Strategy

Source: Research Results, 2019 
As one of the future research directions, the authors consider the extension of one of the steps of the algorithm using the 'new balance system' at the stage of the strategy development. The principles underlying this model were first introduced by Kaplan, Norton (1992) in the study of business strategies under the term 'balanced scorecard'. However, at the modern stage of digitalisation of economy, this model is relevant for all the spheres, as it focuses on a well-balanced development of all the elements of complex systems.

In the tourism sphere this approach implies the establishment of a well-balanced destination. This equilibrium can occur between various factors. For example, in combination of public and private economic entities (including through the implementation of public-private partnership), in combination of infrastructure development with a focus on environment protection, in combination of soft and hard approaches in the process of destination management and other balanced combinations with a view to achieving equilibrium between inputs and outcomes within system.

\section{RESEARCH RESULTS OVERVIEW}

With a view to assessing the national tourism product competitiveness of the Republic of Belarus all the parameters, which are recommended in the methodology of the WEF, were evaluated. The data used in the research includes the assessments derived from the opinion survey as well as statistical data from the credible international and national organisations.

In order to assess the values of the required quantitative indicators, the researchers used credible sources recommended by the WEF in Appendix C 'Data Definitions and Sources' of the Travel \& Tourism Competitiveness Report 2019 (some of them include The World Bank: Doing Business 2019: Training for Reform, World Development Indicators Database; National Consortium for the Study of Terrorism and Responses to Terrorism (START): Global Terrorism Database; World Health Organization: Global Health Observatory Data Repository, World Malaria Report, 2018; Joint United Nations Programme on HIV and AIDS (UNAIDS): AIDSINFO Database; UNESCO: Institute for Statistics, Data Centre, World Heritage List; International Labour Organization: ILOSTAT database; International Telecommunication Union: World Telecommunication Indicators 2018; World Tourism Organization: UNWTO Database; Bloom Consulting: Country Brand Ranking, Tourism Edition; World Trade Organization: Regional Trade Agreements Information System (RTA-IS); International Air Transport Association: SRS Analyser; Yale Center for Environmental Law \& Policy: Wendling, Z.A., J.W. Emerson, D.C. Esty, M.A. Levy, A. de Sherbinin, et al., 2018 Environmental Performance Index. New Haven, CT: Yale Center for Environmental Law \& Policy, 2018; The International Union for Conservation of Nature (IUCN): Red List of Threatened Species 2018, etc.). In cases when no international statistics for a certain indicator were provided for the Republic of Belarus, the data of the National Statistical Committee of the Republic of Belarus was used.

The aforementioned opinion survey was conducted among university professors of the Faculty of International Relations of the Belarusian State University (Minsk, Belarus). The survey form consisted of 33 questions in which participants had a chance to evaluate each of the qualitative indicators on a scale from 1 to 7 . In order to introduce an element of benchmarking into the search it was decided to provide the respondents with the information about level of the same indicators in Poland and Russian Federation (these values were captured from the Travel \& Tourism Competitiveness Report 2019). 
Respondents were also asked to assess whether the evaluated indicator is a strength, weakness, opportunity or threat for the development of the Republic of Belarus as a tourism destination on the international level. This information was used in the analysis using the SWOT-Clock model.

Calculated values of the Travel \& Tourism Competitiveness Index, its subindices and pillars can be perceived as sufficiently reliable for the benchmarking and identifying of competitive advantages, because all the standards proposed by the Methodology of the WEF were respected and all the normalizations were done.

To perform a basic comparative analysis the figures of the global median (from 1 to 7 points) are represented in the Table 1. The decision to choose the global median instead of the global average is explained by the aforementioned fact of presence of extreme outliers in the data. The calculated subindices and the overall Travel \& Tourism Competitiveness Index are represented in Table 1.

Table 1. Assessed Travel \& Tourism Competitiveness Index and Its Subindices and Pillars for the Republic of Belarus, 2019

\begin{tabular}{ccc}
\hline \multicolumn{1}{c}{ Component } & $\begin{array}{c}\text { Assessment for } \\
\text { the Rublic of Belarus, } \\
\text { points from 1 to 7 (best) }\end{array}$ & $\begin{array}{c}\text { Global median, } \\
\text { points from 1 to 7 (best) }\end{array}$ \\
\hline Enabling Environment & $\mathbf{5 . 5 6}$ & $\mathbf{5 . 3 0}$ \\
\hline 1. Business Environment & 4.69 & 5.41 \\
2. Safety and Security & 5.65 & 5.78 \\
3. Health and Hygiene & 6.87 & 5.63 \\
4. Human Resources and Labour Market & 5.20 & 4.74 \\
5. ICT readiness & 5.38 & 4.93 \\
\hline Travel \& Tourism Policy and Enabling Conditions & $\mathbf{4 . 5 0}$ & $\mathbf{4 . 6 4}$ \\
\hline 6. Prioritization of Travel \& Tourism & 4.40 & 6.08 \\
7. International Openness & 3.10 & 3.58 \\
8. Price Competitiveness & 5.84 & 4.63 \\
9. Environmental Sustainability & 4.68 & 4.26 \\
\hline Infrastructure & $\mathbf{3 . 0 1}$ & $\mathbf{4 . 2 7}$ \\
\hline 10. Air Transport Infrastructure & 1.77 & 3.20 \\
11. Ground and Port Infrastructure & 3.34 & 4.64 \\
12. Tourist Service Infrastructure & 3.94 & 4.97 \\
\hline Natural and Cultural Resources & $\mathbf{2 . 5 7}$ & $\mathbf{1 . 8 3}$ \\
\hline 13. Natural Resources & 2.93 & 2.35 \\
14. Cultural Resources & 2.21 & 1.32 \\
\hline Travel \& Tourism Competitiveness Index & $\mathbf{3 . 9 1}$ & $\mathbf{3 . 8 0}$ \\
\hline
\end{tabular}

Source: Research Results, 2019

\section{DISCUSSION}

The Travel \& Tourism Competitiveness Index value of 3.91 places the Republic of Belarus in the middle of the list of 140 countries (around $64^{\text {th }}$ place). It's worth mentioning that some components are at a higher level than the global median. Among them Health and Hygiene, Human Resources and Labour Market, ICT Readiness, Price Competitiveness, Environmental Sustainability, Natural and Cultural Resources. The points above the global median in these subindices mean that these factors contribute to the competitive position of the national tourism product of the Republic of Belarus on the international scale. Despite the fact that some of them are at 
a relatively low level in numerical terms (for example, the assessment of Cultural Resources is only 2.13 points from 7), they all represent competitive advantages of the Belarusian tourism product, because they are higher than the global median (Figure 2). Generally low value of a subindex could be explained by some imperfections in the selected indicators or calculation method.

At the same time, a lot of attention should be paid to the subindices which are significantly lower than the world level. Such factors as Prioritization of Travel \& Tourism (by public authorities), International Openness, and all types of Infrastructure nowadays represent serious weaknesses and reduce the overall Travel \& Tourism Competitiveness Index which aggravates the competitive position of the Belarusian product on the tourism market (Figure 2).

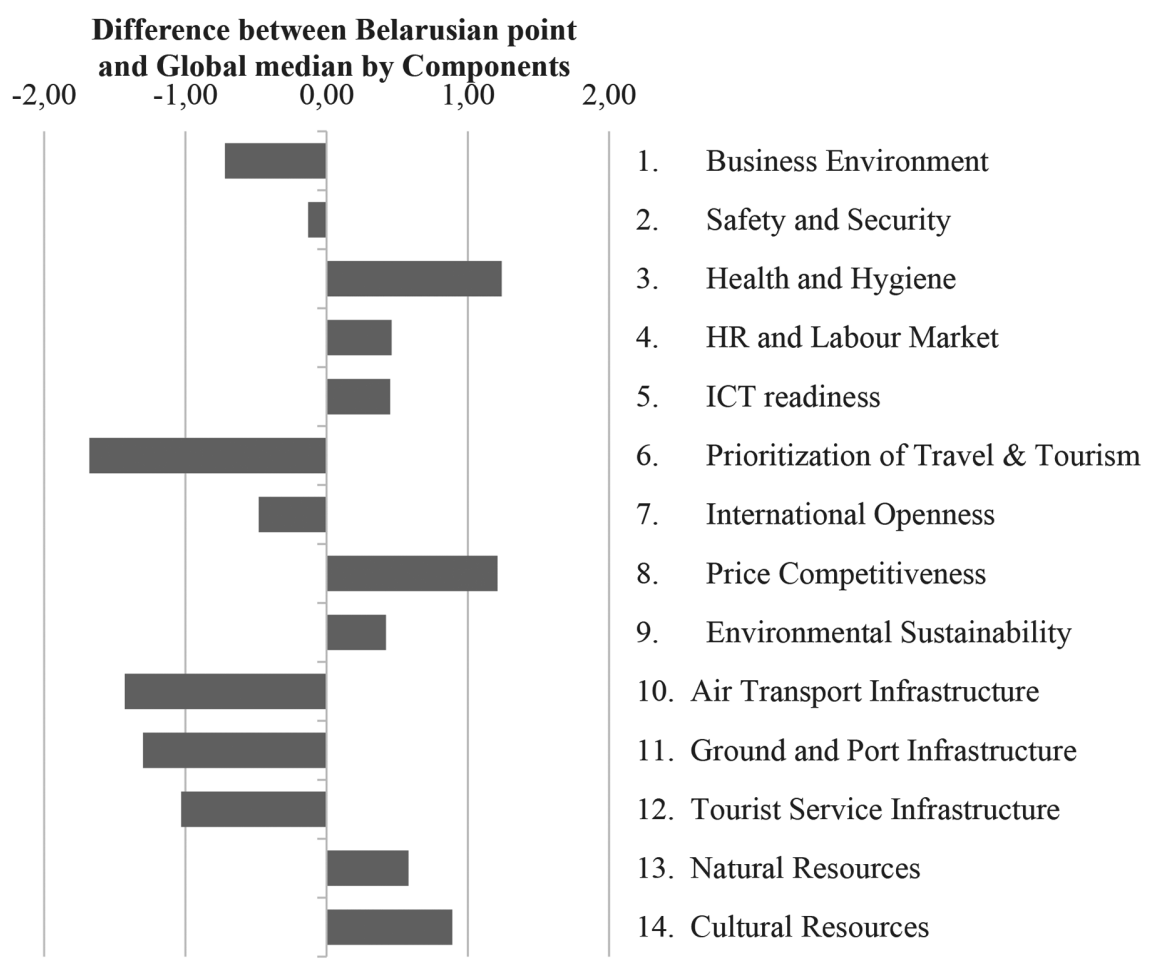

Figure 2. Competitive Advantages Profile of the National Tourism Product of the Republic of Belarus

Source: Research Results, 2019

The authors suggest that, whether the indicator is an advantage or disadvantage according to the assessment made, a more thorough analysis (including for each indicator) should be conducted at the stage of the strategy development in order to identify the reasons influencing the scores for each indicator. Moreover, this analysis can reveal some features that may have an impact on the development of a tourism destination strategy. Special attention should be paid to the comparison not only with the global median, but also with regional competitors.

As a part of the research, all the factors were divided into four groups (Strengths and Weaknesses, Opportunities and Threats) according to the respondents' opinion. The total weighted score for each group was calculated by summing up all the weighted scores for each factor included into the group (Table 2). 
Table 2. Competitiveness Factors Assessed in SWOT-Clock Analysis Groups, 2019

\begin{tabular}{|c|c|c|c|}
\hline Strengths & Weaknesses & Opportunities & Threats \\
\hline 1375 & 1175 & 1125 & 825 \\
\hline
\end{tabular}

Source: Research Results, 2019

Strategic analytical tool SWOT-Clock used by the authors made it possible to identify the key development directions for the Republic of Belarus as a tourism destination. The study revealed that the intensity of Opportunities is greater than the intensity of Threats, while the intensity of Strengths is greater than the intensity of Weaknesses. It means that the Republic of Belarus has only recently passed from the group of leverage strategies to the group of growth strategies (Figure 3). Nowadays the position of the country on the tourism market of Central and Eastern Europe is consistent with growth strategy. This strategy involves a synergistic process of growth and expansion. According to the approaches adopted in strategic management this strategy can be applied in the forms of developing new tourism products, vertical or horizontal integration between countries, and diversification. The strategy also implies an increase in the volume of investments in infrastructure and the creation of favourable conditions for the activities of business units operating in the market.

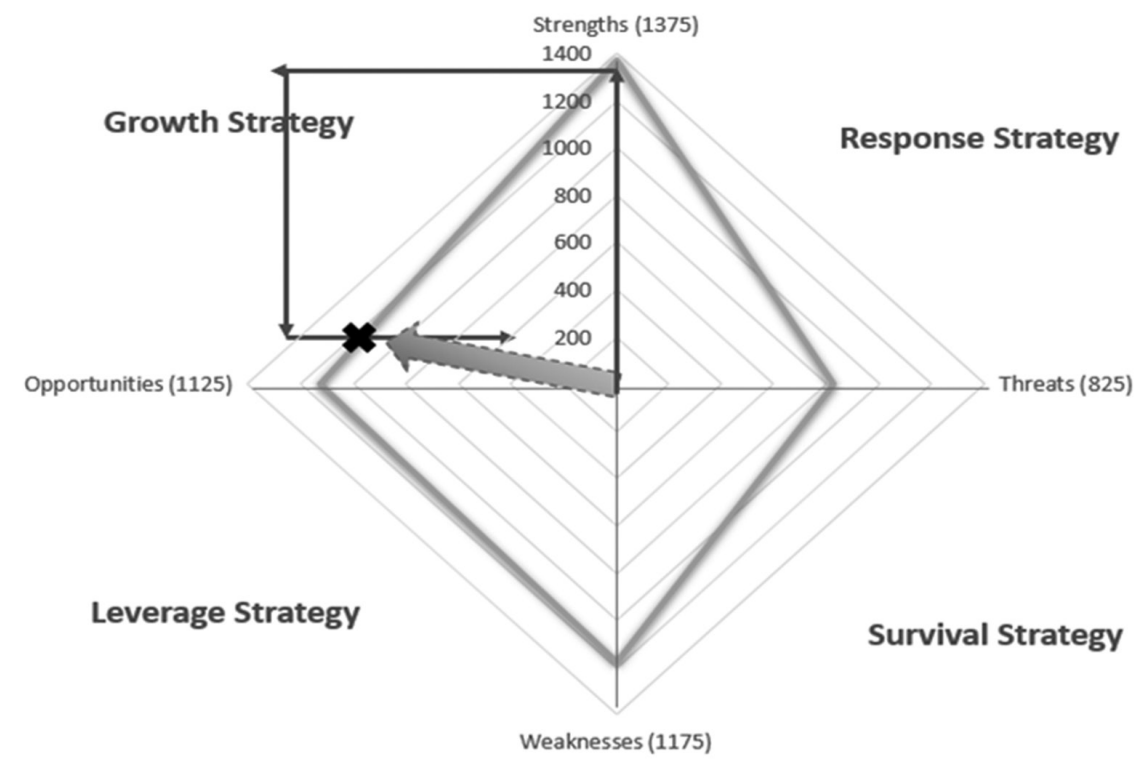

Figure 3. SWOT-Clock Diamond Behaviour Model for the Republic of Belarus as a Tourism Destination

Source: Research Results, 2019

\section{FUTURE RESEARCH DIRECTIONS}

As one of the future research directions, the authors consider the possibility of implementation of this model for the development of the national tourism strategy of the Republic of Belarus. There is also an opportunity to examine aforementioned algorithm in a new sphere or location.

Moreover, one of the main objectives of the further studies is the development of the 'new balance system', which was introduced in this chapter as a means of development of tourism destination strategy. It is assumed that this model can enable authorities and other stakeholders to develop the strategy more effectively on the basis of the equilibrium between all factors in system. 


\section{CONCLUSION}

Thus, it can be noted that the calculation of the Travel \& Tourism Competitiveness Index on the basis of the international standards opens a wide scope for further researches based on benchmarking, comparative analysis, and other tools. Further, the understanding of the country's competitiveness factors and of its position on the international stage serves as a platform for stakeholders' dialogue, which enables them to understand and anticipate emerging trends and risks in global travel and tourism, to adapt their policies, practices and investment decisions, and to accelerate new models that ensure the longevity of this important sector.

As a result of the assessment, it was found out that the level of the tourism product competitiveness in the Republic of Belarus generally corresponds to the global median and global average. But in a number of the analysed indicators the country already has competitive advantage (for example, Human Resources, Price Competitiveness, Natural and Cultural Resources). In order to further improve the country's competitiveness position, develop the tourism sphere, and enhance the country's image on the international arena, it is necessary to focus on the factors that are nowadays below the average. Among them Prioritization of Travel \& Tourism, International Openness, and all the types of the Infrastructure required for the development of the tourism sector.

With a view to formulating tourism development strategy for the Republic of Belarus the SWOT-Clock analysis was conducted. As a result, the authors concluded that Belarus as a tourism destination just recently entered the stage, where growth strategy can be applied, and hence such strategies as market penetration, market expansion, product expansion, and diversification can be implemented for further development and competitiveness increase.

The achievement of progress in competitiveness improvement depends on the implementation of numerous effective solutions. According to authors' opinion, the whole set of activities and measures can be better formulated with the help of 'new balance system'. This model can stimulate well-balanced development of a destination on the basis of realisation of a stable public-private partnership, improvement of the infrastructure with a focus on environment protection or other measures.

In the long-term period, the entire algorithm of destination management and strategy elaboration can be applied to the development of destination. The implementation of this approach will not only allow to assess the competitiveness more effectively, but also to employ various factors in determining the competitive advantages of destination and elaboration of the main development areas.

\section{ACKNOWLEDGEMENTS}

We would like to express our very great appreciation to lecturers and professors of the Faculty of International Relations of the Belarusian State University (Minsk, Belarus) for their participation in the conducted research on the qualitative factors of tourism competitiveness.

We would also like to acknowledge the help provided by Maksim Soshkin, Research and Analysis Specialist from the WEF, who provided us with a clear methodology and formulae for the assessment of the Travel \& Tourism Competitiveness Index. 


\section{REFERENCES}

Bahar, O., \& Kozak, M. (2007). Advancing Destination Competitiveness Research. Journal of Travel \& Tourism Marketing, 22(2), 61-71. https://doi.org/10.1300/j073v22n02_05

Cracolici, M. F., Nijkamp, P., \& Rietveld, P. (2008). Assessment of tourism competitiveness by analysing destination efficiency. Tourism Economics, 14(2), 325-342. https://doi.org/10.5367/000000008784460427

Dupeyras, A., \& MacCallum, N. (2013). Indicators for measuring competitiveness in tourism. https://doi.org/10.1787/5k47t9q2t923-en

Dwyer, L., \& Kim, C. (2003). Destination competitiveness: determinants and indicators. Current issues in tourism, 6(5), 369-414. https://doi.org/10.1080/13683500308667962

Enright, M. J., \& Newton, J. (2004). Tourism destination competitiveness: a quantitative approach. Tourism management, 25(6), 777-788. https://doi.org/10.1016/j.tourman.2004.06.008

Epstein, M. J., \& Manzoni, J. F. (1997). The balanced scorecard and tableau de bord: translating strategy into action. Strategic Finance, 79(2), 28. https://doi.org/10.1016/s0024-6301(97)80925-9

Cucculelli, M., \& Goffi, G. (2016). Does sustainability enhance tourism destination competitiveness? Evidence from Italian Destinations of Excellence. Journal of Cleaner Production, 111, 370-382. https://doi.org/10.1016/j.jclepro.2014.12.069

Gomezelj, D. O., \& Mihalič, T. (2008). Destination competitiveness-Applying different models, the case of Slovenia. Tourism management, 29(2), 294-307. https://doi.org/10.1016/j.tourman.2007.03.009

Goffi, G., Cucculelli, M., \& Masiero, L. (2019). Fostering tourism destination competitiveness in developing countries: The role of sustainability. Journal of Cleaner Production, 209, 101-115. https://doi.org/10.1016/j.jclepro.2018.10.208

Gračan, D., Milojica, V., \& Zubović, V. (2008). Benchmarking in Sports Recreational and Health Tourism in Croatia and Slovenia. In 6th International Scientific Conference Management in the Function of Increasing the Tourism Consumption-Tourism Destination Attractions in the Increased Tourist Expenditure.

Ibañez, J. S., González, L. P., \& Nieto, C. D. N. (2016). Destination competitiveness and sustainable tourism: A critical review. Applied Economics and Finance, 3(2), 1-14.

http://dx.doi.org/10.11114/aef.v3i2.1249

Kapiki, S. (2012). Profit Optimization Strategies in Integrated Resorts-Case Study of the Sani Resort, Chalkidiki. In International Conference, Competition and Innovation in Tourism: New Challenges in an Uncertain Environment' (pp. 193-205).

Kaplan, R. S. (2009). Conceptual foundations of the balanced scorecard. Handbooks of management accounting research, 3, 1253-1269. https://doi.org/10.1016/s1751-3243(07)03003-9

Kozak, M., \& Rimmington, M. (2000). Tourist satisfaction with Mallorca, Spain, as an off-season holiday destination. Journal of Travel Research, 38(3), 260-269. https://doi.org/10.1177/004728750003800308

Mazanec, J. A., Wöber, K., \& Zins, A. H. (2007). Tourism destination competitiveness: from definition to explanation?. Journal of Travel Research, 46(1), 86-95. https://doi.org/10.1177/0047287507302389 
Popesku, J., \& Pavlović, D. (2015). Adapted integrated model of destination competitiveness. In SITCON 2015-Singidunum International Tourism Conference (pp. 9-17). Singidunum University.

https://doi.org/10.15308/sitcon-2015-9-17

Reshetnikov, D. G. (2004). International tourism in the foreign trade system of the Republic of Belarus. Minsk, Belarus, BSU.

Ritchie, J. B., \& Crouch, G. I. (1993). Competitiveness in international tourism: A framework for understanding and analysis. World Tourism Education and Research Centre, University of Calgary.

Ritchie, J. R., Crouch, G. I., \& Hudson, S. (2000). Assessing the Role of Consumers in the Measurement of Destination Competitiveness and Sustainability. Tourism Analysis, 5(23), 69-76.

Ritchie, J. B., \& Crouch, G. I. (2003). The competitive destination: A sustainable tourism perspective. Cabi.

https://doi.org/10.1079/9780851996646.0000

Ritchie, J. R., \& Crouch, G. I. (2010). A model of destination competitiveness/sustainability: Brazilian perspectives. Revista de Administração Pública, 44(5), 1049-1066. https://doi.org/10.1590/s0034-76122010000500003

SWOT-Clock Diamond. (2011-2012). New Dimension. Powerful and effective analysis.

https://www.swotclock.com/

Tsai, H., Song, H., \& Wong, K. K. (2009). Tourism and hotel competitiveness research. Journal of travel \& tourism marketing, 26(5-6), 522-546. https://doi.org/10.1080/10548400903163079

World Economic Forum. (2019). The Travel \& Tourism Competitiveness Report 2019. https://www.weforum.org/reports/the-travel-tourism-competitiveness-report-2019 